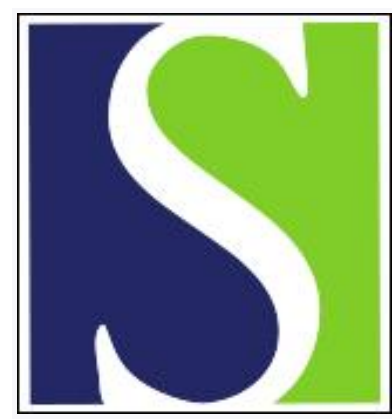

Scand J Work Environ Health 2002;28(2):117-123

https://doi.org/10.5271/sjweh.655

Issue date: Apr 2002

Respiratory health among bleachery workers exposed to ozone and chlorine dioxide

by Olin A-C, Granung G, Hagberg S, Adriansson M, Brisman J, Dalander $\mathrm{O}$, Karlsson B, Torén K

Affiliation: Section of Occupational and Environmental Medicine, Sahlgrenska University Hospital, St Sigfridsgatan 85B, S-412 66 Göteborg, Sweden. Anna-Carin.Olin@ymk.gu.se

Refers to the following texts of the Journal: 1998;24(1):12-17 $1999 ; 25(3): 227-232$

The following articles refer to this text: 2003;29(3):239-245; 2004;30(6):445-449

Key terms: asthma; bleachery worker; chlorine dioxide; irritant; occupational exposure; ozone; pulpmill worker; respiratory health

This article in PubMed: www.ncbi.nlm.nih.gov/pubmed/12019588

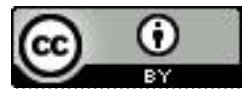




\title{
Respiratory health among bleachery workers exposed to ozone and chlorine dioxide
}

\author{
by Anna-Carin Olin, MD, ${ }^{1}$ Gerd Granung, RN, ${ }^{1}$ Stig Hagberg, MSc, ${ }^{1}$ Magnus Adriansson, MD, ${ }^{2}$ \\ Jonas Brisman, MD, ${ }^{3}$ Olle Dalander, MD, ${ }^{2}$ Berndt Karlsson, MD, ${ }^{4}$ Kjell Torén, $M D^{1,3}$
}

\begin{abstract}
Olin A-C, Granung G, Hagberg S, Adriansson M, Brisman J, Dalander 0, Karlsson B, Torén K. Respiratory health among bleachery workers exposed to ozone and chlorine dioxide. Scand J Work Environ Health 2002;28(2):117123.
\end{abstract}

Objectives This study investigated the possibility of occupational exposure to ozone increasing the risk of obstructive airway disease among bleachery workers.

Methods Bleachery workers ( $=129)$ from two Swedish pulp mills using ozone for bleaching were studied together with referents $(\mathrm{N}=80)$ from adjacent paper mills. The pulp mills had previously used chlorine dioxide as the bleaching agent. Testings included spirometry, methacholine challenge testing, and questionnaires. Area samplings showed sporadic ozone levels exceeding $0.9 \mathrm{ppm}$.

Results There was a greater prevalence of wheezing (25\%) among the bleachery workers with a history of gassings (from ozone, chlorine, or sulfur dioxide) than among those without gassings (18\%) and among the referents $(13 \%)$. Among the current smokers the fraction with a slightly increased bronchial responsiveness to methacholine was greater among the bleachery workers reporting gassings than among those that had not been gassed. For the period from 1992 to 1996, when the mills were using ozone, there was an increased incidence rate of wheezing among the workers in the bleachery (incidence rate ratio 2.3, 95\% confidence interval 1.6-5.8). Conclusions Repeated exposure to irritants increases the risk of asthma-like symptoms. This finding reinforces the view that repeated peak exposures to irritants must be prevented in pulp mills.

Key terms asthma, irritants, occupational, pulpmill workers.

Pulpmill workers can be exposed to a wide variety of irritant gases, especially chlorine or chlorine dioxide (1) and sulfur dioxide (2). Some epidemiologic studies have shown an increased prevalence of wheezing and decreased lung function (3-5), especially among bleachery workers. In that group a history of gassing events seems to be a major risk factor (3), especially for smokers (5). Exposure to irritants is also of importance in other occupations (6). In a longitudinal study of 211 metalworkers, self-reported gassings with chlorine were associated with increased bronchial hyperresponsiveness and impaired lung function (7).
Ozone was introduced as a bleaching agent in the Swedish pulp industry in 1992 (8). Process disturbances caused bleachery workers to be accidentally exposed to high concentrations of ozone (over $1 \mathrm{ppm}$ ). In ambient air the concentrations of ozone can vary, but in Swedish cities they seldom exceed $0.15 \mathrm{ppm}$. Ozone is a respiratory irritant, and respiratory health effects had been described already at the end of the 19th century. The symptoms following acute exposure to high concentrations that have been described include nose and throat irritation, coughing, dyspnea, chest pain, and severe fatigue (9). It has been concluded in two reviews that

1 Section of Occupational and Environmental Medicine, Sahlgrenska University Hospital, Göteborg, Sweden.

2 Sodra Cell, Mönsterås, Sweden.

3 Department of Respiratory Medicine and Allergology, Sahlgrenska University Hospital, Göteborg, Sweden.

4 Occupational Medicine, Department of Public Health and Clinical Medicine, Umeå University, Umeå, Sweden.

Reprint requests to: Dr Anna-Carin Olin, Section of Occupational and Environmental Medicine, Sahlgrenska University Hospital, St Sigfridsgatan 85B, S-412 66 Göteborg, Sweden. [E-mail: Anna-Carin.Olin@ymk.gu.se] 
short-term exposure to ozone at ambient concentrations will result in airway inflammation $(10,11)$. It is however unclear whether repeated exposure to high levels contribute to the development of a new onset of asthma among adults (10).

We report on a cross-sectional study of a large group of bleachery workers with long-term occupational exposure to chlorine dioxide, and more recent exposure to ozone following its introduction as a bleaching agent. The specific aim of the study was to investigate the extent to which occupational ozone exposure was associated with respiratory health effects, especially with the occurrence of obstructive airway disease.

\section{Subjects and methods}

All process workers, maintenance workers, and laboratory workers $(\mathrm{N}=139)$ in the bleaching department from two sulfate pulp mills (A and B) were selected as exposed subjects. Both mills had been using chlorine or chlorine dioxide as bleaching agents since the 1950s. In mill A, chlorine dioxide was replaced by ozone in 1992, and in mill B the replacement took place in 1993. Chlorine dioxide had however been used periodically up to 1995.

The study was carried out in 1996. Ten of the exposed subjects refused to participate. All the process workers $(\mathrm{N}=93)$ from two adjacent paper mills were recruited as unexposed referents. The paper mills made printing paper. Dust measurements in similar paper mills have shown low levels (around $0.5 \mathrm{mg} / \mathrm{m}^{3}$ ) of paper dust (12). Thirteen refused to participate. In all, 129 bleachery workers and 80 referents were included in the final study (table 1).

All the subjects were sent a respiratory questionnaire, containing items similar to previous questionnaires (13-15). The key items regarding symptoms and diseases are shown in the appendix. All the subjects underwent baseline spirometry with a dry wedge spirometer (Vitalograph®). The subjects performed at least three technically acceptable trials, and the largest value for the vital capacity (VC), forced vital capacity (FVC), and forced expiratory volume in 1 second $\left(\mathrm{FEV}_{1.0}\right)$ were registered and compared with predicted values (16). The methacholine challenge test was performed according to published guidelines (17). Briefly, the test commenced with the inhalation of saline diluent, and the first technically acceptable post-diluent $\mathrm{FEV}_{1.0}$ recorded 2 minutes later was used as the control value. The methacholine was delivered with continuously doubling concentrations, starting with $0.5 \mathrm{mg} / \mathrm{ml}$ and stopping at 32 $\mathrm{mg} / \mathrm{ml}$, unless the provocative concentration causing a $20 \%$ decrease in $\mathrm{FEV}_{1.0}\left(\mathrm{PC}_{20}\right)$ had been reached earlier. The subjects known to have asthma started with a methacholine concentration of $0.125 \mathrm{mg} / \mathrm{ml}$. Three different cut-off points were used, $\mathrm{PC}_{20} \leq 4 \mathrm{mg} / \mathrm{ml}, \mathrm{PC}_{20} \leq 8$ $\mathrm{mg} / \mathrm{ml}$ and $\mathrm{PC}_{20} \leq 32 \mathrm{mg} / \mathrm{ml}$. Blood samples were obtained from all the subjects, and the sera were frozen immediately at $-20^{\circ} \mathrm{C}$. The sera were analyzed with respect to Phadiatop ${ }^{\circledR}$ using commercial kits in accordance to the manufacturer's instructions (Pharmacia Upjohn Diagnostics, Uppsala, Sweden).

Atopy was defined as a positive Phadiatop ${ }^{\circledR}$ test (18), whereby class 0 was regarded as nonatopic and class 1 as atopic.

The items used from the questionnaire are shown in the appendix. Current asthma symptoms were defined as an affirmative answer to item 11. Physician-diagnosed asthma was defined as an affirmative answer to item 7.

Asthma was defined as $\mathrm{PC}_{20} \leq 8 \mathrm{mg} / \mathrm{ml}$ and a positive response to the questions about wheezing (item 9) or dyspnea (item 8) with symptom-free intervals in between (item 10), current asthma symptoms (item 11) or physician-diagnosed asthma (item 7).

The local ethics committee approved the study, and an informed written consent was obtained from all the subjects prior to their inclusion in the study

\section{Exposure}

All the mills had been using chlorine dioxide as a bleaching agent since the 1950s, and chlorine dioxide was replaced by ozone as the bleaching agent between

Table 1. Basic data about the ozone-exposed workers and referents.

\begin{tabular}{|c|c|c|c|c|c|c|c|c|c|c|c|c|c|c|c|c|}
\hline \multirow[t]{3}{*}{ Group } & \multicolumn{2}{|c|}{$\begin{array}{l}\text { Age } \\
\text { (years) }\end{array}$} & \multicolumn{2}{|c|}{$\begin{array}{l}\text { Employment } \\
\text { time (years) }\end{array}$} & \multicolumn{3}{|c|}{ Gender } & \multicolumn{6}{|c|}{ Smoking } & \multicolumn{3}{|l|}{ Atopy a } \\
\hline & \multirow[t]{2}{*}{ Mean } & \multirow[t]{2}{*}{ SD } & \multirow[t]{2}{*}{ Mean } & \multirow[t]{2}{*}{$\mathrm{SD}$} & \multirow{2}{*}{$\begin{array}{l}\text { Male } \\
(\mathrm{N})\end{array}$} & \multirow{2}{*}{$\begin{array}{l}\text { Female } \\
(\mathrm{N})\end{array}$} & \multirow{2}{*}{$\begin{array}{l}\text { Both } \\
(\mathrm{N})\end{array}$} & \multicolumn{2}{|c|}{ Smokers } & \multicolumn{2}{|c|}{ Ex-smokers } & \multicolumn{2}{|c|}{ Never smokers } & \multirow{2}{*}{$\begin{array}{l}\text { Exposed } \\
\text { (N) }\end{array}$} & \multicolumn{2}{|c|}{ Those with atopy } \\
\hline & & & & & & & & $\mathrm{N}$ & $\overline{\%}$ & $\mathrm{~N}$ & $\%$ & $\mathrm{~N}$ & $\%$ & & $\mathrm{~N}$ & $\%$ \\
\hline $\begin{array}{l}\text { Exposed } \\
(\mathrm{N}=129)\end{array}$ & 41.8 & 9.8 & 18.2 & 7.7 & 116 & 13 & 129 & 18 & 14 & 41 & 32 & 70 & 54 & 128 & 25 & 20 \\
\hline $\begin{array}{l}\text { Referents } \\
(\mathrm{N}=80)\end{array}$ & 42.4 & 9.7 & 19.6 & 11.4 & 71 & 9 & 80 & 14 & 18 & 20 & 25 & 46 & 57 & 79 & 20 & 25 \\
\hline
\end{tabular}

a Atopy was defined as positive Phadiatop ${ }^{\circledR}$ test. 
1992 and 1993. Under normal conditions, the concentration of ozone in a pulp mill is low $(<40 \mathrm{ppb})$. In the process of bleaching, ozone gas is used at a concentration of $9 \%$. During accidents, for example, leakages or breaks of pipes, it is our estimation that the ozone concentration can briefly be very high (>10000 ppb) in positions where ozone is still concentrated. Stationary measurements were performed in the mixing and ozonator rooms (the critical areas for high ozone exposure) of the mills. We used a continuous analyzing ultraviolet-photometric instrument (Environics Series 300 Ozone Analyser Computerized, Environics Inc, United States). These measurements register the variation in ozone concentrations by continuous analyses. The response time for the analyzer is 10 seconds. The measurement equipment was positioned in the center of the rooms, which were all $>100 \mathrm{~m}^{2}$, and the distance from the actual leak influenced the levels registered, at least in cases of smaller leaks.

Table 2 presents the results of measurements on 366 days. The table indicates the percentage of days (24 hours) when the instrument indicated ozone levels exceeding $50 \mathrm{ppb}$ and $300 \mathrm{ppb}$. The ozone levels exceeded $900 \mathrm{ppb}$ one or more times on six of these days. In 1994 a surveillance system initiating an alarm and reinforced ventilation when the ozone concentration reached $300 \mathrm{ppb}$ were introduced.

The estimation of the personal exposure, however, was based on the subjects' self-reports. In the respiratory questionnaire the following exposure-related questions were put to the subjects: (i) "Have you been exposed to ozone resulting in coughing, wheezing, breathlessness or pain in the thorax? If 'yes', when did this occur?"; (ii) "Have you been exposed to chlorine dioxide resulting in coughing, breathlessness or wheezing? If 'yes', when did this occur?"; (iii) "Have you been exposed to sulfur dioxide resulting in coughing, breathlessness or wheezing? If 'yes', when did this occur?" "Ozone gassing" was defined as a positive response to question 1, "chlorine gassing" as a positive response to question 2, and "sulfur dioxide gassing" as a positive response to question 3. In the main analyses the workers were placed into the following three groups: (i) those who reported "gassings" either from ozone, chlorine or sulfur dioxide, (ii) bleachery workers not reporting of any gassings, (iii) unexposed referents. The subgroups of workers reporting ozone gassings were treated separately in additional analyses.

\section{Statistical methods}

The statistical analyses were performed with the statistical software package SAS version 8 (SAS Institute, Cary, NC, USA). The univariate statistical analyses of the basic data for the subjects were based on the Student's
Table 2. Results from the stationary measurements of the ozone concentration in two pulp mills ( $\mathrm{A}$ and $\mathrm{B})$. ( $\mathrm{N}=$ number of sampling days)

\begin{tabular}{ccc}
\hline & $\begin{array}{l}\text { Days with ozone } \\
\text { concentration } \\
\text { over 50 ppb (\%) }\end{array}$ & $\begin{array}{l}\text { Days with ozone } \\
\text { concentration } \\
\text { over 300 ppb (\%) }\end{array}$ \\
\cline { 2 - 3 } Mixing room & & \\
Mill A ( $N=28)$ & 60.1 & 32.3 \\
Mill B (N=224) & 25.5 & 0.3 \\
Ozonator room & & \\
Mill A ( $N=31)$ & 90.3 & 6.5 \\
Mill B $(\mathrm{N}=83)$ & 13.2 & 2.3 \\
\hline
\end{tabular}

test and the chi-square test. In general the P-values have been reported. Prevalences have either been expressed as prevalence ratios or as fractions. The significance testing was based on the Mantel-Haenszel test. The incidence rate of new onset of wheezing after the introduction of ozone bleaching (1992-1995, from 1993 for mill B) was calculated as new-onset wheeze/100 person-years among bleachery workers and referents. The risk for new-onset wheezing was calculated as the incidence rate ratio.

In the analyses of categorical variables, univariate analyses were performed, mostly followed by stratification for smoking, atopy, or gender. In the final analyses of the prevalent respiratory symptoms, stratification for smoking and atopy was used. The 95\% confidence intervals (95\% CI) relied on the test-based method (19). Trends were analyzed with the Kruskall-Wallis test.

A proportional hazards model (Cox's) assessed the association between the exposure estimates and the outcome variables, after adjustment for smoking habits, age, and atopy. The referents were used as reference, and the significance of the slope in the multivariate regression model was based on Wald statistics.

\section{Results}

\section{Exposure}

Ozone gassings were reported by 55 (43\%) of the bleachery workers during the period from 1992 to 1996. During the same period chlorine gassings were reported by $20(16 \%)$ workers and sulfur dioxide gassings by $18(14 \%)$ workers. Ten bleachery workers reported gassings from ozone, chlorine, and sulfur dioxide. In a logistic regression model controlling for atopy, gender, and smoking among the exposed workers, the strongest predictor for reporting ozone gassings was previous chlorine gassing [odds ratio (OR) 2.4, 95\% CI 0.96-5.9). No relation was found between smoking habits, employment time or atopy and the reporting of gassing events. 
Table 3. Prevalence of current asthma symptoms, physician-diagnosed asthma, ever wheezing, and nocturnal dyspnea among the bleachery workers and referents. The prevalence ratios were stratified for atopy and smoking habits, but, in the table, only the smoking stratification is shown. $(95 \% \mathrm{Cl}=95 \%$ confidence interval)

\begin{tabular}{|c|c|c|c|c|c|c|c|c|c|c|}
\hline \multirow[t]{3}{*}{ Respiration effect } & \multicolumn{4}{|c|}{ Never smokers } & \multicolumn{4}{|c|}{ Ever smokers } & \multirow{3}{*}{$\begin{array}{l}\text { Prevalence } \\
\text { ratio }\end{array}$} & \multirow[t]{3}{*}{$95 \% \mathrm{Cl}$} \\
\hline & \multicolumn{2}{|c|}{ Exposed $(\mathrm{N}=70)$} & \multicolumn{2}{|c|}{ Referents $(\mathrm{N}=46)$} & \multicolumn{2}{|c|}{ Exposed ( $\mathrm{N}=59)$} & \multicolumn{2}{|c|}{ Referents ( $\mathrm{N}=34$ ) } & & \\
\hline & $\begin{array}{l}\text { Total } \\
\text { number }\end{array}$ & $\begin{array}{l}\text { Those with } \\
\text { respiratory } \\
\text { effect (N) }\end{array}$ & $\begin{array}{l}\text { Total } \\
\text { number }\end{array}$ & $\begin{array}{l}\text { Those with } \\
\text { respiratory } \\
\text { effect (N) }\end{array}$ & $\begin{array}{l}\text { Total } \\
\text { number }\end{array}$ & $\begin{array}{l}\text { Those with } \\
\text { respiratory } \\
\text { effect (N) }\end{array}$ & $\begin{array}{l}\text { Total } \\
\text { number }\end{array}$ & $\begin{array}{l}\text { Those with } \\
\text { respiratory } \\
\text { effect (N) }\end{array}$ & & \\
\hline Current asthma symptoms & 68 & 12 & 43 & 3 & 55 & 7 & 34 & 3 & 1.8 & $0.9-3.4$ \\
\hline Ever wheezing & 68 & 13 & 46 & 5 & 58 & 17 & 34 & 5 & 1.8 & $1.1-3.0$ \\
\hline Physician-diagnosed asthma & 66 & 4 & 44 & 1 & 57 & 4 & 34 & 2 & 1.8 & $0.7-4.7$ \\
\hline Nocturnal dyspnea & 68 & 3 & 46 & 3 & 58 & 6 & 34 & 3 & 1.0 & $0.5-1.9$ \\
\hline Exertional dyspnea & 70 & 11 & 45 & 4 & 58 & 12 & 35 & 2 & 2.0 & $1.1-3.9$ \\
\hline Cough with phlegm & 69 & 11 & 46 & 4 & 56 & 6 & 33 & 2 & 1.7 & $0.9-3.2$ \\
\hline
\end{tabular}

Table 4. Prevalence ratios of physician-diagnosed asthma and ever wheezing for the bleachery workers according to the Cox regression models adjusted for smoking, gender, age, and atopy.

\begin{tabular}{lcc}
\hline Symptom & $\begin{array}{c}\text { Prevalence } \\
\text { ratio }\end{array}$ & 95\% confidence interval \\
\hline Physician-diagnosed asthma & 2.2 & $0.2-21.8$ \\
Ever wheezing & 2.6 & $1.0-46.3$ \\
\hline
\end{tabular}

\section{Respiratory health effects}

There was an increased prevalence of wheezing and exertional dyspnea among the bleachery workers, and the increase still remained after stratification for smoking and atopy (table 3 ). The findings were the same with stratification for atopy, gender, or smoking. The prevalence ratios obtained from the Cox regression modeling are shown in table 4.

When the bleachery workers were divided into those reporting or not reporting gassings, the prevalences of respiratory symptoms were highest among the gassed workers (table 5). A similar pattern was seen after stratification for smoking habits (not shown in the table), the most exceptional trend being found for ever smokers (referents 18\%, bleachery workers without gassings $19 \%$, and "gassed" bleachery workers $37 \%$; test for trend $\mathrm{P}=0.05)$. Fifteen subjects were classified as having asthma [11 among the bleachery workers and 4 among the referents (prevalence ratio 1.5, 95\% CI 0.73.2)]. The highest prevalence of asthma occurred for the gassed workers $(10 \%, \mathrm{~N}=9)$, followed by $6 \%(\mathrm{~N}=2)$ among the ungassed bleachery workers and $5 \%(\mathrm{~N}=4)$ among the referents (P-value for trend 0.25).

The prevalences of respiratory symptoms, with the workers divided into those with and without ozone gassings (other gassings being disregarded) are shown in table 6 . The differences diminished between the workers reporting ozone gassings and those that did not, mainly because workers gassed by chlorine dioxide were accumulated among the bleachery workers not reporting ozone gassings.

Eleven subjects reported an onset of wheeze during the period from 1992 to 1995 , when the mills were

Table 5. Prevalence of current asthma, physician-diagnosed asthma, ever wheezing, nocturnal dyspnea, exertional dyspnea, and cough with phlegm among the bleachery workers with and without reported gassings and among the referents.

\begin{tabular}{|c|c|c|c|c|c|c|c|c|c|c|}
\hline \multirow[t]{3}{*}{ Respiratory effect } & \multicolumn{3}{|c|}{$\begin{array}{l}\text { Bleachery workers } \\
\text { with "gassings" }(\mathrm{N}=95)\end{array}$} & \multicolumn{3}{|c|}{$\begin{array}{l}\text { Bleachery workers } \\
\text { without "gassings" }(\mathrm{N}=34)\end{array}$} & \multicolumn{3}{|c|}{ Referents $(\mathrm{N}=80)$} & \multirow{3}{*}{$\begin{array}{l}\text { P-value } \\
\text { for } \\
\text { trend }\end{array}$} \\
\hline & \multirow[t]{2}{*}{$\begin{array}{l}\text { Total } \\
\text { number }\end{array}$} & \multicolumn{2}{|c|}{$\begin{array}{l}\text { Those with } \\
\text { respiratory } \\
\text { effect }\end{array}$} & \multirow[t]{2}{*}{$\begin{array}{l}\text { Total } \\
\text { number }\end{array}$} & \multicolumn{2}{|c|}{$\begin{array}{l}\text { Those with } \\
\text { respiratory } \\
\text { effect }\end{array}$} & \multirow[t]{2}{*}{$\begin{array}{l}\text { Total } \\
\text { number }\end{array}$} & \multicolumn{2}{|c|}{$\begin{array}{l}\text { Those with } \\
\text { respiratory } \\
\text { effect }\end{array}$} & \\
\hline & & $\mathrm{N}$ & $\%$ & & $\mathrm{~N}$ & $\%$ & & $\mathrm{~N}$ & $\%$ & \\
\hline Current asthma symptoms & 90 & 15 & 17 & 33 & 4 & 12 & 77 & 6 & 8 & 0.08 \\
\hline Ever wheezing & 93 & 24 & 25 & 33 & 6 & 18 & 80 & 10 & 13 & 0.03 \\
\hline Physician-diagnosed asthma & 91 & 5 & 5 & 32 & 3 & 9 & 78 & 3 & 4 & 0.51 \\
\hline Nocturnal dyspnea & 93 & 8 & 9 & 33 & 1 & 3 & 80 & 6 & 8 & 0.57 \\
\hline Exertional dyspnea & 95 & 20 & 21 & 33 & 3 & 9 & 80 & 6 & 8 & 0.009 \\
\hline Cough with phlegm & 93 & 13 & 14 & 32 & 4 & 13 & 79 & 6 & 8 & 0.19 \\
\hline
\end{tabular}


Table 6. Prevalence of current asthma symptoms, physician-diagnosed asthma, ever wheezing, nocturnal dyspnea, and cough with phlegm among the bleachery workers with and without reported gassings to ozone and among the referents.

\begin{tabular}{|c|c|c|c|c|c|c|c|c|c|c|}
\hline \multirow[t]{3}{*}{ Respiratory effect } & \multicolumn{3}{|c|}{$\begin{array}{l}\text { Bleachery workers with } \\
\text { ozone gassings }(\mathrm{N}=55)\end{array}$} & \multicolumn{3}{|c|}{$\begin{array}{l}\text { Bleachery workers without } \\
\text { ozone gassings }(N=74)\end{array}$} & \multicolumn{3}{|c|}{ Referents $(\mathrm{N}=80)$} & \multirow{3}{*}{$\begin{array}{l}\text { P-value } \\
\text { for } \\
\text { trend }\end{array}$} \\
\hline & \multirow[t]{2}{*}{$\begin{array}{l}\text { Total } \\
\text { number }\end{array}$} & \multicolumn{2}{|c|}{$\begin{array}{l}\text { Those with } \\
\text { respiratory } \\
\text { effect }\end{array}$} & \multirow[t]{2}{*}{$\begin{array}{l}\text { Total } \\
\text { number }\end{array}$} & \multicolumn{2}{|c|}{$\begin{array}{l}\text { Those with } \\
\text { respiratory } \\
\text { effect }\end{array}$} & \multirow[t]{2}{*}{$\begin{array}{l}\text { Total } \\
\text { number }\end{array}$} & \multicolumn{2}{|c|}{$\begin{array}{l}\text { Those with } \\
\text { respiratory } \\
\text { effect }\end{array}$} & \\
\hline & & N & $\%$ & & $\mathrm{~N}$ & $\%$ & & $\mathrm{~N}$ & $\%$ & \\
\hline Current asthma symptoms & 55 & 8 & 15 & 68 & 11 & 16 & 77 & 6 & 8 & 0.21 \\
\hline Ever wheezing & 54 & 14 & 26 & 72 & 16 & 22 & 80 & 10 & 13 & 0.05 \\
\hline Physician-diagnosed asthma & 54 & 1 & 9 & 69 & 7 & 10 & 78 & 3 & 4 & 0.79 \\
\hline Nocturnal dyspnea & 54 & 4 & 7 & 72 & 5 & 7 & 80 & 6 & 8 & 0.97 \\
\hline Exertional dyspnea & 55 & 12 & 22 & 73 & 11 & 15 & 80 & 6 & 8 & 0.02 \\
\hline Cough with phlegm & 54 & 6 & 11 & 71 & 11 & 15 & 79 & 6 & 8 & 0.44 \\
\hline
\end{tabular}

using ozone, 9 being bleachery workers and 2 being referents. The prevalence odds ratio (Mantel-Haenszel) for new-onset wheezing when controlled for smoking habits was 2.3 (95\% CI 0.8-6.7). The incidence rate of newonset wheezing was $2.8 / 100$ person-years for the bleachery workers versus $0.9 / 100$ person-years for the referents (incidence rate ratio $3.1,95 \%$ CI 1.6-5.8).

There were only marginal differences in regard to lung function; among the never smokers, the $\mathrm{FEV}_{1.0}$ was $101 \%$ for the exposed workers as compared with $104 \%$ for the referents $(\mathrm{P}=0.19)$. The methacholine challenge test was performed by 203 subjects (97\%); 36 reached $\mathrm{PC}_{20} \leq 4 \mathrm{mg} / \mathrm{ml}, 46$ reached $\mathrm{PC}_{20} \leq 8 \mathrm{mg} / \mathrm{ml}$, and 94 reached $\mathrm{PC}_{20} \leq 32 \mathrm{mg} / \mathrm{ml}$. The fraction reaching $\mathrm{PC}_{20}$ at different concentrations was not connected with exposure status, although there was a tendency towards lower $\mathrm{PC}_{20}$ among the gassed workers. For the currently smoking bleachery workers, the prevalence of $\mathrm{PC}_{20} \leq 32 \mathrm{mg} /$ $\mathrm{ml}$ was more frequent $(\mathrm{P}=0.05$, Fisher's exact test) among those reporting gassings ( 7 of $10,70 \%$ ) than among those not reporting them ( 1 of $7,13 \%)$. This phenomenon was not seen among the never smokers (52\% versus $42 \%$ ) or among the ex-smokers (46\% versus $50 \%$ ).

\section{Discussion}

Several important observations can be made from this study. The ozone measurements indicated that ozone levels around at least $1 \mathrm{ppm}$ can occur; during our sampling period they occurred during $2 \%$ of the days. The bleachery workers reported more asthma symptoms than did the referents, and for workers that had been subjected to gassings the positive response rate was still higher. The incidence of new-onset wheezing was significantly increased among the bleachery workers when ozone was being used as a bleaching agent.
There were several potential biases in this study. As in most populations of industrial workers, selection bias is of importance. Bleachery workers with respiratory problems may leave the pulp mill or obtain a new job in the adjacent paper mill. A few papermill workers reported chlorine gassings, but excluding them did not change the results. The prevalence of atopy was $25 \%$ for the referents, compared with $20 \%$ for the bleachery workers, the result indicating a slight selection bias.

We estimated that the workers with the highest exposure were those who had been present when an acute leak had occurred, and next came the workers who searched for leaks. However, it was not feasible to measure the exposure for these workers, and hence the exposure classification was based on self-reports of gassings. The use of this classification may have introduced a potential source of information bias. This method has however been used by others $(3,4)$. Kennedy et al (3) used the question "Have you ever been gassed?", and Henneberger et al (4) used "Have you ever been gassed by chlorine or chlorine dioxide?" Since ozone does not have such an obvious smell as does, for instance, chlorine dioxide, we had to alter the wording: "Have you been exposed to ozone with consequent coughing, wheezing, breathlessness or pain in the thorax?" Such wording may be more sensitive to recall bias, since workers with preexisting respiratory symptoms may be more liable to recall gassings. If so, one would expect the prevalence of atopy to be increased among those reporting gassings. The prevalence of atopy among the gassed bleachery workers was $20 \%$ versus $21 \%$ among those not reporting gassings, and in the logistic regression modeling atopy was not a predictor for reporting gassings.

Bleachery workers may also be more eager to report symptoms such as wheezing and exertional dyspnea than are referents. Such bias was impossible to estimate in this study, and the lack of such an estimation may, to 
some extent, explain the increased prevalence of reported respiratory symptoms among bleachery workers. Questions about respiratory symptoms are probably more influenced by recall bias than are questions about specific conditions, such as physician-diagnosed asthma. In this study we observed the same exposure-dependent pattern for physician-diagnosed asthma as for reported symptoms, although the low prevalence of physiciandiagnosed asthma meant it had no formal statistical significance. This is to some extent an argument against recall bias in respect to the reporting of symptoms.

Chlorine dioxide and sulfur dioxide are confounders, since they may also cause asthma-like symptoms and are strongly associated with ozone gassings. Previous chlorine gassings may also act as effect modifiers. The risk of developing respiratory symptoms as a result of ozone gassings may increase among previously gassed workers, since the inflammatory response due to repeated chlorine peaks may not have completely subsided. There are also data indicating that accidental occupational exposure to chlorine can lead to long-lasting impairment of airway caliber (7).

We chose to use the old Mantel-Haenszel method for analyzing prevalence ratios, instead of calculating prevalence odds ratios. Calculating prevalence ratios is an adequate way of analyzing cross-sectional data (20). In these simple models we were able to control for smoking and atopy. In addition, we also analyzed the prevalence ratios with Cox regression models, which contained more covariates. These models gave somewhat higher risk estimates, but without altering the main findings.

It was consistently observed that bleachery workers, especially if gassed, showed an increased prevalence of wheezing and that smokers seemed to be at still greater risk. We also found an association between reported gassings and an increased prevalence of methacholine responsiveness $\left(\mathrm{PC}_{20}<32 \mathrm{mg} / \mathrm{ml}\right)$ for the current smokers, but not for the nonsmokers (never + former smokers). That smokers emerge as a susceptible subgroup agrees with the results of other studies $(4,7)$.

After 1991, 55 workers reported ozone gassings, and during this period there was an increased risk for newonset wheezing among the exposed workers. Nine bleachery workers reported new-onset wheezing, and one of them reported chlorine gassings after 1992. This reconstruction of incidence data has some limitations. Workers who left the mills in between the start of the bleaching process and the present investigation would not be included, the result being selection bias. There was probably an overrepresentation of diseased workers among the not-included workers with a resulting underestimation of the observed assessed risk estimate.

In a previous study we also found that gassed bleachery workers had an increased output of nitric oxide in their exhaled air and that ozone gassings were an independent predictor of an increased output of nitric oxide (21). Hence occupational exposure to ozone gassings may initiate an airway inflammation that can cause respiratory symptoms and asthma.

Respiratory health effects due to occupational exposure to ozone have been reported for many other occupational groups, such as welders (9), those engaged in the production of plastic bags (22), different kinds of outdoor workers (23-24), aircraft personnel (25), cement-kiln workers (26), and persons working with equipment inducing high-voltage discharge (27-28). The acute symptoms that were reported have mainly been cough, headache, and dyspnea. These studies are mainly case reports, and controlled studies of workers with long-term occupational exposure to ozone are lacking.

Our study confirms what has been described by other groups: that repeated exposure to irritants increases the risk for asthma symptoms. Even if our results indicate adverse respiratory health effects as a result of occupational exposure to ozone, the cross-sectional design of the study makes it impossible to determine whether the increased risk of asthma symptoms is due to gassings from ozone, chlorine dioxide, or sulfur dioxide. Because of the limited power of the study, we were unable to find a statistically significant increased risk of asthma, even though an increased prevalence was observed among the exposed workers. The study population will be followed by a prospective longitudinal study with improved ability to distinguish the effect of ozone from that of other irritants.

The results underscore that repeated peak exposures to irritants must be controlled in pulp mills and also better prevented. Most important would be to control accidental exposures.

\section{Acknowledgments}

Our study was supported by the Swedish Council for Worklife Research, Torsten and Ragnar Söderbergh's Medical Foundation, Sodra Cell AB, MoDo Paper AB, and the Göteborg Medical Society.

\section{References}

1. Courteau J-P, Cushman R, Bouchard F, Quévillon M, Chartrand A, Bhérer L. Survey of construction workers repeatedly exposed to chlorine over a 3 to 6 month period, I: exposure and symptomatology. Occup Environ Med 1994;51:219-24.

2. Andersson E, Nilsson T, Persson B, Wingren G, Torén K. Mortality from asthma and cancer among sulfite mill workers. Scand J Work Environ Health 1998;24(1):12-7. 
3. Kennedy S, Enarson DA, Janssen RG, Chan-Yeung M. Lung health consequences of reported accidental chlorine gas exposures among pulp mill workers. Am Rev Respir Dis 1991; 143:74-9.

4. Henneberger PK, Ferris BG, Sheehe PR. Accidental gassing incidents and the pulmonary function of pulp mill workers. Am Rev Respir Dis 1993;148:63-7.

5. Henneberger PK, Lax MB, Ferris BG. Decrements in spirometry values associated with gassing events and pulp mill work. Am J Respir Crit Care Med 1996;153:225-31.

6. Das R, Blanc PD. Chlorine gas and the lung [review]. Toxicol Ind Health 1993;9:439-55.

7. Gautrin D, Leroyer C, Infante-Rivard C, Ghezzo H, Dufour JG, Girard D, et al. Longitudinal assessment of airway caliber and responsiveness in workers exposed to chlorine. Am J Respir Crit Care Med 1999;160:1232-7

8. Torén K, Blanc PD. The history of pulp and paper bleaching: respiratory health effects. Lancet 1997;349:1316-8.

9. Kleinfeld M, Giel CP. Clinical manifestations of ozone poisoning: report of a new source of exposure. Am J Med Sci 1956;231:638-43

10. Balmes, J. The role of ozone exposure in the epidemiology of asthma. Environ Health Perspect 1993;suppl 101: suppl 4.

11. Krishna MT, Mudway I, Kelly FJ, Frew AJ, Holgate ST. Ozone, airways and allergic disease. Clin Exp Allergy 1995;25:1150-8.

12. Meding B, Torén K, Karlberg A-T, Hagberg S, Wass K. Evaluation of skin symptoms among workers at a Swedish paper mill. Am J Ind Med 1993;23:721-8

13. Lundbäck, B. Asthma, chronic bronchitis and respiratory symptoms: prevalence and important determinants: the obstructive lung disease in northern Sweden study I [dissertation]. Umeå (Sweden): Umeå University, 1992.

14. Torén K, Brisman J, Järvholm B. Asthma and asthma-like symptoms in adults assessed by questionnaires. Chest 1993;104:600-8.

15. Torén K, Hermansson B-A. Incidence rate of adult-onset asthma in relation to age, sex, atopy and smoking: a Swedish population-based study of 15813 adults. Int J Tuberc Lung Dis 1999;3:1-6.

16. Berglund E, Birath B, Bjure J, Grimby G, Kjellmer I, Sandqvist L, et al. Spirometric studies in normal subjects, III: static lung volumes and maximum voluntary ventilation with a note of physical fitness. Acta Med Scand 1963;173:185-92.

17. Sterk PJ, Fabbri LM, Quanjer PH, Cockcroft DW, O'Byrne PM, Anderson SD, et al. Airway responsiveness: standardized challenge testing with pharmacological, physical and sensititizing stimuli in adults. Eur Respir J 1993;6(suppl 16):53-83.

18. Matricardi PM., Nisini R, Pizzolo JG, d'Amelio R. The use of Phadiatop ${ }^{\circledR}$ in mass-screening programmes of inhalant allergies: advantages and limitations. Clin Exp Allergy 1990; 20:151-5.

19. Miettinen O. Estimability and estimation in case-referent studies. Am J Epidemiol 1976;103:226-35.

20. Axelson O, Fredriksson M, Ekberg K. Use of prevalence ratio $\mathrm{v}$. the prevalence odds ratio as a measure of risk in cross sectional studies. Occup Environ Med 1994;51:574.

21. Olin A-C, Ljungkvist G, Bake B, Hagberg S, Henriksson L, Torén K. Exhaled nitric oxide among pulpmill workers reporting gassing incidents involving ozone and chlorine dioxide. Eur Respir J 1999;14:828-31.

22. Fabbri L, Mapp C, Rossi A, Sarto F, Trevisan A, De Rosa E. Pulmonary changes due to low level occupational exposure to ozone. Med Lav 1979;4:307-12.

23. Raaschou-Nielsen O, Nielsen M-L, Gehl J. Traffic-related air-pollution: exposure and health effects in Copenhagen street cleaners and cemetery workers. Arch Environ Health 1995;50:207-13.

24. Brauer M, Blair J, Vedal S. Effect of ambient ozone exposure on lung function in farm workers. Am J Respir Crit Care Med 1996;154:981-7.

25. Reed D, Glaser S, Kaldor J. Ozone toxicity symptoms among flight attendants. Am J Ind Med 1980;1:43-54.

26. Sanderson WT, Almaguer D, Kirk LH III. Ozone-induced respiratory illness during the repair of a portland cement kiln. Scand J Work Environ Health 1999;25(3):227-32.

27. Lee HS, Wang YT, Tan KT. Occupational asthma due to ozone. Singapore Med J 1989;30:485-7.

28. Edwards EK. Ozone production by dermatologic phototherapy equipment. Cutis 1981;28:433-34.

Received for publication: 20 March 2001

\section{Appendix}

\section{Items used in the questionnaire answered by the bleachery workers and the referents}

7. Have you been diagnosed as having bronchial asthma by a physician?

If "yes", in what year?

8. Have you at any time after 15 years of age been awakened at night by an attack of shortness of breath?

If "yes", in what year did you first notice it?

9. Have you at any time after 15 years of age had an attack of wheezing, whistling or a noisy sound in your chest when breathing?

If "yes", in what year did you first notice it?

10. Is your breathing normal between attacks?

11. Have you had attacks of asthma symptoms (ie, episodical breathing problems or shortness of breath) during the last 12 months? The symptoms may exist simultaneously with or without cough or wheezing. 